\title{
The politics of educational exchange: Turkish education in Eurasia
}

\section{Lerna K. Yanik}

To cite this article: Lerna K. Yanik (2004) The politics of educational exchange: Turkish education in Eurasia, Europe-Asia Studies, 56:2, 293-307, DOI: 10.1080/0966813042000190551

To link to this article: https://doi.org/10.1080/0966813042000190551

Published online: 05 Oct 2010.

Submit your article to this journal $\square$

Џلll Article views: 255

Citing articles: 11 View citing articles 5 


\title{
The Politics of Educational Exchange: Turkish Education in Eurasia
}

\author{
LERNA K. YANIK
}

THIS ARTICLE ASSESSES THE ROLE of educational exchange as a foreign policy tool. ${ }^{1}$ It investigates public and private educational ties that were established between Turkey and Turkic populations of Eurasia, including the Turkic republics of the former Soviet Union after 1991 - a period which is considered to be the beginning of a new era in Turkish foreign policy making. ${ }^{2}$ After spending the Cold War as a buffer state, Turkey felt the need to redefine its role in the international arena in the aftermath of the Cold War. The emergence of the Turkic republics played an important role in this redefinition process.

This redefinition included the highlighting of Turkey's common ethnic bonds, especially with the Turkic republics of the former Soviet Union. Turkey emphasised common history and traditions, attempted to create a common alphabet, and furthermore created and reorganised certain institutions that worked to highlight this ethnic commonality. Educational ties established especially with the Turkic republics and with countries in the Balkans and Eurasia were an important part of this cultural reorientation policy pursued by the Turkish state.

The highlighting of these common ethnic bonds in the early 1990s was quite unusual for Turkey and the Turkish elites, since it was something that had not been done openly since the last days of the Ottoman Empire. In the early 1920s, when establishing the Turkish Republic, and afraid of angering the Soviet Union, the founding fathers of modern Turkey opted not to associate the country, at least in the political sense, with the Turkic groups that had become part of the newly established USSR. Despite this political dissociation, official Turkish history, which was rewritten in the early days of modern Turkey, nevertheless kept the link to the Turkic Republics of the former Soviet Union by accepting Turkistan, the geographical area that mostly corresponds to today's Turkic republics in Central Asia, as the ancestral homeland of the Turks in Turkey. Following the collapse of the Soviet Union, however, after an almost 70-year gap, Turkish elites began to re-establish the long-forgotten political ties with the Turkic republics. These political ties were full of nuances that aimed to underline the common ethnic ground that Turkey and the Turkic republics shared.

Education was and still is an important part of this cultural reorientation policy developed by Turkey. Very much like the educational campaign modern Turkey embarked upon in the early days of the Republic to create the 'Turk', this second 
educational campaign had two very important goals. Turkish elites, very optimistically, thought that educating today's students meant creation of the elites who later would be in charge of the transformation towards a market economy and democracy in their countries. ${ }^{3}$ More importantly, however, the goal was to create a stratum of people who would be well versed in Turkish culture and language, which then would act as a bridge between their countries and Turkey. The students coming out of this educational experience were expected to bear the 'Turkic identity' that the Turkish elites thought was in the making since the Turkic republics gained their independence in 1991. In other words, like many scholars who previously highlighted the link between education and identity, ${ }^{4}$ Turkish officials were quick to realise the importance of education as a powerful mechanism of identity creation and social change. As one former Turkish minister of national education stated:

These children, during their education, will get the chance to know their Turkish friends closely and thus will become the foundation stones for the common cause. Furthermore, when they return to their countries after finishing their education, they will become the architects of the great Turkish world ... 5

In terms of educational exchange there were two main trends. The first was that students, especially at the university level, were invited to study in Turkey on scholarships distributed by the Turkish state. Second, there were educational institutions, mostly at the secondary education level, established in the Turkic Republics of the former Soviet Union and Eurasia by the Turkish Ministry of Education and by various foundations, especially ones known to have ties to the Nurcu community of Fetullah Gülen. The involvement of the Nurcu community as a non-state actor in this educational exchange indicates a degree of delegation in the process of creating a collective Turkic identity. This is an interesting point because the Turkish state most of the time preferred to keep a tight monopoly on culture and national identity issues. Overall, when considered as a whole, from the perspective of the Turkish state, all these educational exchange ties, both public and private, can be regarded as a long-term investment. The success of this investment will only be determined in the coming decades.

\section{The students from Eurasia}

Educational exchange, especially inviting students from the Turkic Republics as well as from Eurasia, was one of the top priorities of Turkish officials from the early days. These students were seen as the foundation stones of the 'Turkish Renaissance' or as part of the modernisation of the 'Turkish World' in the twenty-first century. ${ }^{6}$ Labeled the 'Great Student Exchange Project', the aim, as stated briefly before, was to educate the future generation of elites of the newly independent states in Eurasia. To this end, starting in the 1992-93 academic year, the Turkish state offered 7,000 higher education scholarships and 3,000 secondary school scholarships to students from the Turkic Republics and approximately 1,000 scholarships to students from Eurasian countries. In the first year of this Great Student Exchange Project, of the 10,000 scholarships that were offered, students coming from the Turkic Republics accepted 4,879 higher education scholarships and 1,659 high school scholarships. ${ }^{7}$ When 
distributing all these scholarships, in order to show that these countries were equally important for Turkey, the Turkish Ministry of National Education was very careful to allocate equal numbers of scholarships $\left(2,000\right.$ per country) ${ }^{8}$

In addition to inviting students on scholarship to Turkey, Turkey also offered various training programmes and seminars. For example, following a protocol signed by the ministers of foreign affairs, Turkey also started to train diplomats from the Turkic Republics in 1992. This was a training programme that also included several months of training in the Turkish language. ${ }^{9}$ Between 1992 and 1998 a total of 297 diplomats were trained. This number included diplomats from the Turkic Republics as well as diplomats from countries like Bosnia-Herzegovina, Albania, and Ukraine. ${ }^{10}$ There were also two-week seminars that aimed to introduce Turkish culture and the national education system to teachers from the Turkic Republics and various Turkish communities. The total number of trainees who took part in these seminars between 1995 and 1999 was $910 .{ }^{11}$

Furthermore, to handle these scholarships and the student traffic, the Turkish Ministry of National Education established the Department of Overseas Education within the ministry in May 1992. While the ministry stated that 'providing educational assistance for citizens and their children living abroad' was the primary goal of this newly established department, the duties of the department also included 'to develop educational cooperation between Turkey and the Turkic Republics' ${ }^{12}$

Inviting students on scholarships to Turkey, however, did not always operate smoothly. It had inherent problems that the Turkish elites themselves also acknowledged. These problems eventually led to a decrease in the number of students who came to study in Turkey. The first and foremost problem was economic. The amount of money that Turkey spent for students and their scholarships was not enough to cover all costs adequately. There were criticisms that Turkey had invited more students than it could handle, and thus the scholarships were too small and often were not paid on time. ${ }^{13}$ The Turkish Ministry of National Education, quite self-critically, was well aware of the insufficiency of these scholarships and stipends as early as 1993. ${ }^{14}$ Second, there were criticisms that the Turkish authorities were not paying serious attention to the selection of students coming from the Turkic Republics and other Turkish and Turkic communities elsewhere. Turkey, according to this line of argument, had chosen quantity over quality, i.e. had opted for bringing the average student rather than the best and the brightest. This was considered a reason for the high drop-out rate and limited the chance of success of the project from the beginning. Former Turkish President Süleyman Demirel, in a 1998 interview, claimed that Turkey was paying the utmost attention to this selection process. The Turkish authorities, he argued, initially had aimed for a 50\% degree completion rate and now the rate was around $70 \%$, with which they were quite content. ${ }^{15}$

Finally, tension between Turkey and Uzbekistan became one of the reasons leading to a decrease in the number of students from the Turkic Republics. Soon after the electoral victory of the Welfare Party in 1996, the Uzbek government claimed that some members of the Welfare Party and Uzbek dissidents living in Turkey were trying to turn Uzbek students in Turkey into 'Islamic fundamentalists'. ${ }^{16}$ Consequently, the Uzbek government, which in September 1994 had been 'calling on Turkey to educate [its] students', ${ }^{17}$ withdrew 1,298 students in 1997. Moreover, the 
TABLE 1

StUdents on Scholarship IN TURKeY From Eurasia, 1997-2002

\begin{tabular}{lrrrrr}
\hline & 1997 & 1999 & 2000 & 2001 & 2002 \\
\hline Azerbaijan & 1,793 & 1,169 & 815 & 630 & 616 \\
Kazakhstan & 1,178 & 775 & 669 & 625 & 617 \\
Kyrgyzstan & 804 & 762 & 814 & 721 & 699 \\
Uzbekistan & 438 & 195 & 10 & 6 & 3 \\
Turkmenistan & 2,226 & 1,368 & 1,186 & 970 & 822 \\
Asian countries & 1,710 & 1,613 & 1,553 & 1,384 & 1,283 \\
Balkan countries & 1,396 & 1,543 & 1,558 & 1,701 & 1,611 \\
Total & $\mathbf{9 , 5 4 5}$ & $\mathbf{7 , 4 2 5}$ & $\mathbf{6 , 6 0 5}$ & $\mathbf{6 , 0 3 7}$ & $\mathbf{5 , 6 5 1}$ \\
\hline
\end{tabular}

Source: Compiled from data available at www.meb.gov.tr, accessed 10 September 2003.

Uzbek government blamed Turkey for harbouring Uzbek dissidents, some of whom were accused of plotting an assassination against the Uzbek President, Islam Karimov, in February 1999. ${ }^{18}$ This further increased tensions between Turkey and Uzbekistan and, as Table 1 indicates, another 243 students were withdrawn between 1997 and 1999, bringing the total number of Uzbek students in Turkey to 195. By October 2002, according to Turkish Ministry of National Education statistics, there were only three Uzbek students left studying in Turkey. ${ }^{19}$

The Turkish government, however, denied that Uzbek dissidents were being harboured in Turkey ${ }^{20}$ and that the Uzbek government was withdrawing its students. Prime Minister Ecevit, for instance, rejected the allegations that the withdrawals were related to 'fundamentalism'. He stated that the Uzbek students were being withdrawn due to 'unnecessarily created distrust'. ${ }^{21}$ Ahat Andican, Minister in Charge of Relations with Turkic Republics, stated that

There was no such withdrawal whatsoever. When the protocol about educating 10,000 students in Turkey was signed in 1994, the Uzbek government stated that they would use this quota as they needed. So, there never have been 2,000 Uzbek students in Turkey and now [August 1997] there are $400 .{ }^{22}$

However, although there were no other major tensions between other Turkic Republics and Turkey, there was an overall decrease in the numbers of students coming to Turkey. As Table 1 shows, the decreasing number of students indicates a loss of momentum in the Great Student Exchange Project after 1997. With the exception of students coming from the Balkan countries, there has been a decline in the number of students coming from all of the Turkic republics and other Asian countries. Overall, while the total number of students in Turkey in 1997 was 9,545, this number dropped to 6,037 in 2001 and 5,651 in 2002.

Table 2 puts the total number of scholarships distributed to students from Eurasia including the Turkic republics between 1992 and 2002 as 21,871. During this period, of the 21,871 scholarships distributed, 11,017 were revoked, marking the success rate as approximately $50 \%$.

However, these numbers conflict with those from another report prepared by the Turkish Ministry of National Education. According to this report, which appeared in 2001, the total number of students who came to Turkey from the Turkic Republics 
TABLE 2

Number of Scholarships Distributed AND ReVoKed, 1992-2002

\begin{tabular}{lccc}
\hline Countries & $\begin{array}{c}\text { Scholarships } \\
\text { distributed }\end{array}$ & $\begin{array}{c}\text { Scholarships } \\
\text { revoked }\end{array}$ & $\begin{array}{c}\text { Number of } \\
\text { graduates }\end{array}$ \\
\hline Azerbaijan & 3,195 & 1,467 & 1,102 \\
Kazakhstan & 2,691 & 1,463 & 611 \\
Kyrgyzstan & 1,987 & 958 & 330 \\
Uzbekistan & 1,981 & 1,705 & 273 \\
Turkmenistan & 4,235 & 1,850 & 1,563 \\
Asian countries & 3,960 & 2,125 & 552 \\
Balkan countries & 3,822 & 1,449 & 762 \\
Total & $\mathbf{2 1 , 8 7 1}$ & $\mathbf{1 1 , 0 1 7}$ & $\mathbf{5 , 1 9 3}$ \\
\hline
\end{tabular}

Source: Compiled from the Turkish Ministry of National Education Website, http://www.meb.gov.tr/ stats/apk2003/icindekilersayisalveriler2003.pdf, accessed 10 September 2003.

and the Turkish/Turkic communities on scholarship between 1992 and 1999 was 17,995 , the number of graduates was 3,169, and the number who left without completing their degrees (including the students withdrawn by Uzbekistan) was $7,401 .{ }^{23}$ In early 1995 , for example, of the 11,437 students who came to Turkey from the Turkic Republics and other Turkic/Turkish communities, approximately 2,500 had already returned to their countries without completing their degrees. ${ }^{24} \mathrm{~A}$ report that appeared in the newspaper Milliyet painted a direr picture. According to this report, of the 18,690 students who came to Turkey, only (approximately) 3,000 were able to get their degrees; for various reasons, 9,000 of them had lost their scholarships and 2,300 had simply dropped out without completing their degrees. Again, according to this report, most of these 2,300 students who dropped out ended up not returning to their own countries and many of them took employment illegally in Turkey ${ }^{25}$ In June 2001, however, Abdulhaluk Çay, the Minister in Charge of Relations with the Turkic States, put the total number of students who came to Turkey on scholarships as 19,000 , the total number of graduates as 4,500, and the current number of students in Turkey as 13,000, with 1,300-1,400 additional students coming to Turkey every year. ${ }^{26}$ A Ministry of Foreign Affairs official put the total number of scholarships distributed to students from the Turkic Republics and other Turkish communities between 1992 and late 2001 as 20,500. ${ }^{27}$ These numbers, however, are no more than a statistic that only gives a very rough indication of what the Turkish state has done so far for this Great Student Exchange Project. Only time and, of course, the next generation of elites will show whether or not Turkey will get its returns from its long-term investment. Despite all these ups and downs, Turkey, at the moment, is still keen on maintaining all these programmes. Former minister Çay stated that Turkey would focus more on bringing students at the graduate level to Turkey and would slowly improve conditions for these students by establishing help desks in major cities. ${ }^{28}$ Likewise, in December 2001, during budget discussions in the Turkish Grand National Assembly, İsmail Cem, Minister of Foreign Affairs at the time, reiterated the importance of this educational exchange both for Turkey and for the countries in Eurasia and stated that

In order to be able to expedite the transition to democracy and to market economy in the 
TABLE 3

Elementary and Secondary Schools, and Turkish Language Teaching CEntres Established in Eurasia by the Turkish Ministry of National EDUCATION, 2001-2002 ACADEMIC YEAR

\begin{tabular}{lcccc}
\hline & Schools & Students & TLTC & TLTC students \\
\hline Azerbaijan & 2 & 452 & 1 & 40 \\
Kazakhstan & - & 101 & 2 & 101 \\
Kyrgyzstan & 3 & 698 & 1 & 480 \\
Uzbekistan & 1 & 98 & - & - \\
Turkmenistan & 2 & 999 & 2 & 399 \\
Tajikistan & - & 97 & 1 & 97 \\
Moldova & 1 & 76 & - & - \\
Total & $\mathbf{9}$ & $\mathbf{2 , 5 2 1}$ & $\mathbf{7}$ & $\mathbf{1 , 1 1 7}$ \\
\hline
\end{tabular}

Source: MEB Istatistik 2003, http://www.meb.gov.tr/stats/apk2003/icindekilersayisalveriler2003.pdf, accessed 10 September 2003.

Turkic Republics of the former Soviet Union as well as other Turkic communities, and to develop cultural, economic and political relations, we give special importance to the scholarship project. We are in full coordination with the related ministries, in order to provide the best education possible for the students who will become the ruling cadres of their country. ${ }^{29}$

\section{Turkish schools in the Turkic Republics and Eurasia}

Part of this educational exchange consisted of institutions established at various levels both by the Turkish Ministry of National Education and by private foundations in Eurasia after 1991 (see Tables 3 and 4). By early 1995, as part of 'creating the next generation of elites', the Turkish Ministry of National Education established four Anatolian high schools, ${ }^{30}$ six Anatolian professional schools, two elementary schools, three Turkish Language Teaching Centres (TLTC) and the Turk-Kazakh Hoca Ahmet Yesevi University in Kazakhstan. ${ }^{31}$ In 1998 the Turk-Kyrgyz Manas University, which was established with the support of the Turkish government, was added to this list. However, private schools established especially by the Nurcu community, and to a lesser degree by other groups like the Foundation for Research on the Turkish World, outnumbered the schools and universities established by the Turkish Ministry of National Education. Furthermore, the Turkish state and these private initiatives all had a different geographical focus when establishing their respective educational institutions. With the exception of Tajikistan and Moldova, the educational institutions the Turkish state established were limited to the Turkic republics. The primary focus of the Nurcu community was still the Turkic republics, but businessmen from this community also established numerous educational institutions at various levels elsewhere in the Commonwealth of Independent States and around the world in countries ranging from Afghanistan to the United Kingdom. In 1998 the community was even reported to be considering the idea of establishing a Turkish-American University in New Jersey. ${ }^{32}$

At first sight, the greater number of private Turkish schools than state ones could have been regarded as a 'win-win' situation for Turkey and the Turkish state since 
TABLE 4

Number of Turkish Private Schools Opened in the Commonwealth of Independent States (CIS), FEBRUARY 1997

\begin{tabular}{lcrcccc}
\hline & Schools & Students & Teachers & Universities & Students & Academic staff \\
\hline Azerbaijan & 16 & 2,653 & 397 & 3 & 1,407 & 102 \\
Kazakhstan & 31 & 5,885 & 85 & 2 & 171 & 96 \\
Kyrgyzstan & 11 & 2,093 & 291 & 2 & 378 & 31 \\
Uzbekistan & 17 & 3,174 & 210 & & & 70 \\
Turkmenistan & 14 & 2,549 & 318 & 2 & 501 & \\
Tajikistan & 5 & 694 & 107 & & & \\
Russian Fed. $^{\text {a }}$ & 4 & 358 & 53 & & & \\
East Siberia $_{\text {Tatarstan }}$ & 5 & 438 & 97 & & & \\
Chuvashia & 8 & 1,798 & 218 & 2 & 83 & 30 \\
Karachai-Cherkessia & 1 & 160 & 21 & & & \\
Dagestan & 1 & 93 & 11 & & 390 & 43 \\
Bashkortostan & 3 & 454 & 72 & 2 & & \\
Crimea & 3 & 462 & 88 & & & \\
Georgia & 1 & 181 & 28 & & & \\
Ukraine & 3 & 244 & 48 & & & \\
Moldova & 2 & 112 & 49 & & & \\
Total & 2 & 235 & 40 & $\mathbf{3 7}$ & $\mathbf{2 , 9 3 0}$ & \\
\hline
\end{tabular}

Note: ${ }^{\text {a }}$ Excluding regions specified separately.

Source: Istatistik Turkce 97, http://www.meb.gov.tr/stats/myhtm150.htm, accessed 24 April 2001.

Turkish culture, language and education were being transported to these countries at no cost to the Turkish state. In 1998, for example, it was estimated that 40,000 students were being taught Turkish at the schools associated with the Nurcu community. ${ }^{33}$ These schools, especially the ones related to the Nurcu community (which was regarded as the 'post-modern' face of Islam in Turkey, blending 'Turkish nationalism with political Islam, the idea of Islamic brotherhoods, the savoir-vivre of the West and economic neo-liberalism'), ${ }^{34}$ offered students around Eurasia a superior education, teaching four languages (Turkish, English, Russian and the local language) at once along with strict discipline and respect for family (which is something very revered in the East) in return for no or very little monetary obligation for students in most cases. Coupled with these features, the presence of teachers who were working with missionary zeal quickly made these institutions 'star' schools, in which parents competed for the privilege of enrolling their children. ${ }^{35}$ Put differently, this was basically third parties displaying a very positive image of Turkey, the Turks and Turkishness. As a consequence, these schools initially gained the full approval of Turkish officials. For example, former Turkish presidents Turgut Özal and Süleyman Demirel were reported to have written reference letters for some of these entrepreneurs who established schools in Kazakhstan and Georgia. ${ }^{36}$

What was interesting in this initial 'symbiosis' between the Turkish state and the Nurcu community, which is traced back to Said-i Nursi and his writings, was the nature and the mission of Fetullah Gülen and his followers. Born in 1873, in eastern Anatolia, Said-i Nursi's goal, in brief, was to keep Islam away from the materialism of the West. ${ }^{37}$ Consequently, Nursi promoted the revival of Islamic values in the late Ottoman and early republican periods. In order to achieve this goal of Islamic revival, 
Nursi, in Şerif Mardin's words, believed that his followers should be 'enlightened ... by demonstrating the truths of religion in the manner most appropriate to the understanding of that century'. ${ }^{38}$ In other words, from Nursi's perspective, being a good Muslim and reaching Islam without the influence of the West required education, learning and mastering new sciences. ${ }^{39}$ Given the emphasis on education in Nurcu teachings, in a sense, the idea of opening schools and universities both in Turkey and in 53 different countries of the world was the realisation of this 'post-modern' approach of the Nurcu community as well as the teachings of Said-i Nursi. These schools were spreading Turkish identity (with the Islamic side highlighted) with the help of a curriculum almost matching Western educational standards at schools financed by community members whose fortunes had their roots in the basic tenets of capitalism. However, Fetullah Gülen denied that these schools were directly tied to him. Rather, he said, these schools belonged to his entrepreneur followers, whom he encouraged to open schools in Turkey and elsewhere. ${ }^{40}$ Fetullah Gülen, in a series of interviews that appeared in the newspaper Yeni Yüzyil in January 1998, explained the reasons for establishing these schools as follows:

I first sent my friends to Azerbaijan. My friends took this offer to the Azerbaijanis and the Azerbaijanis accepted the offer. I found their interest encouraging. We said, 'this is a good thing'. We thought, 'we could enter the education world [in these countries] before anybody else ... and we could fill the gap and leave no place neither for Iran nor for Turan'. People shouldered these educational activities like they shouldered the National Independence War [of Turkey].... I saw the Turkish [sic] States of the former Soviet Union as oppressed and unjustly treated. As the son of a great state, I could never digest this humiliation. Turkey is not a small state but due to the conditions of that day, it is a state with limited abilities. ${ }^{41}$

Despite the existence of Turkish teachers, teaching Turkish language and culture, Fetullah Gülen and his followers also rejected the idea that these schools were preaching religion and propagating Turkish nationalism. Gülen insisted that their educational operations were nothing more than retaliation against the missionary activities of 'others'. ${ }^{42}$ In his words, 'constructing a congregation was more important than constructing a mosque', ${ }^{43}$ and the existence of 'ties from the heart', he said, was the reason he and his followers preferred the Turkic Republics to establish their educational enterprises. ${ }^{44}$

In other words, the Nurcu community saw themselves as lobbyists carrying 'Turkish culture' and 'the idea of Turkishness' abroad through education and the post-modern face of Islam. In Fetullah Gülen's words, 'the success of these schools was also becoming the success of Turkey'. ${ }^{45}$ Initially, this characteristic of the Nurcu community helped to draw support from non-Nurcu businessmen engaged in business in the former Soviet Union ${ }^{46}$ as well as Turkish statesmen. ${ }^{47}$ In November 1997, for example, Prime Minister Bülent Ecevit, during a trip to Denmark, visited a school belonging to the Nurcu community, and frequently expressed his constant support for these schools as well as for Fetullah Gülen. ${ }^{48}$

However, two events did great damage to this 'educational symbiosis' between the Turkish state and the Nurcu community. First, in February 1999 there was a failed assassination attempt against the Uzbek President, Islam Karimov. In April 1999, following this assassination attempt, the Uzbek government accused several Turkish 
businessmen in Uzbekistan who were claimed to be connected with the Nurcu community of having ties to this assassination attempt, ${ }^{49}$ and closed down all schools related to the Nurcu community, sent all teachers of Turkish nationality back to Turkey and, according to certain reports, even barred the graduates of these schools from attending universities in Uzbekistan. ${ }^{50}$ This was followed by the closure of six schools and one Turkish Language Teaching Centre operated by the Turkish Ministry of Education. ${ }^{51}$ As Table 3 indicates, in late 2002 there was only one school in Uzbekistan operated by the Turkish Ministry of National Education, which only students of Turkish nationality attended.

While relations between Turkey and Uzbekistan turned sour soon after the incident in Uzbekistan, another event took place in Turkey that raised doubts about the 'post-modern' intentions of the Nurcu community. In June 1999 secretly taped recordings of Fetullah Gülen, calling on his followers to penetrate into high positions in the Turkish state 'patiently and secretly' and 'not to surface until a certain point', were disclosed and created a major uproar in Turkey. While Fetullah Gülen dismissed these accusations as mere slander and conspiracy, ${ }^{52}$ a year later, in August 2000, Turkish prosecutors took the case to the State Security Court of Turkey. ${ }^{53}$ In March 2003 Fetullah Gülen was still being tried in absentia, accused of attempting to overthrow the secular government of Turkey. ${ }^{54}$

All these incidents were received differently by Turkish elites and even created conflicting views among them. In June 2000, for example, in a report prepared by Turkey's ambassadors to the Turkic republics for the Turkish Ministry of Foreign Affairs, the ambassadors stated their support for the schools associated with the Nurcu community. ${ }^{55}$ Additionally, the then Prime Minister Bülent Ecevit continued to give his support to the educational efforts of the Nurcu community. In March 2000, during a visit to Albania, he visited one of the schools known to be financed by a member of this community, and was reported to have expressed his appreciation to the school administrators, 'knowing that this may be criticised by other people' ${ }^{56}$ On the other hand, President Necdet Sezer, during his trip to Kazakhstan in October 2000, did not visit one of these schools on the grounds that 'private enterprises could not be visited during an official state visit'. ${ }^{57}$ Furthermore, in an attempt to reduce the Turkish state's dependence on 'private entrepreneurs', Sezer asked the permission of Kazakh President Nursultan Nazarbaev to establish schools that would be operated by the Turkish Ministry of National Education. ${ }^{58}$ Sezer was also reported to have received similar permission from Uzbekistan with which just a year earlier Turkey had troubled relations. ${ }^{59}$ In yet another statement, Çay denied allegations that the plans to establish schools that would be operated by the Turkish state aimed to undercut the schools associated with the Nurcu community. ${ }^{60}$

The Turkish Ministry of National Education, on the other hand, started to take special measures to prevent a repetition of the events in Uzbekistan. Although the ministry is by law unable to intervene in the Turkish private schools opened abroad, it decided to keep a close eye on their curricula and textbooks. ${ }^{61}$ Moreover, the Turkish Higher Education Council, which organises the university entrance examinations in Turkey, decided to exclude private universities connected with the Nurcu community from their listings. ${ }^{62}$ Despite all these events in Uzbekistan and Turkey, school closures were limited only to Uzbekistan and, very recently, to the Russian 
Federation. About ten institutions known to have ties with the Nurcu community have been reported to have been closed down in Karachai-Cherkessia, Bashkortistan and elsewhere around the Russian Federation on the grounds that the schools were 'very close to the Nurcu community, which has been pursuing a pan-Turkist and pan-Islamist ideology'. ${ }^{63}$ Nevertheless, the educational enterprise of the Nurcu community, which was estimated to spend around 1.5 billion dollars and believed to employ 7,000 teachers, according to 1998 estimates, continued to operate in 54 countries of the world including Turkey. ${ }^{64}$

Apart from the schools connected with the Nurcu community, there were other private schools established and operated by other foundations, like the Turkish World Research Foundation, known to have pan-Turkic leanings. By early 2001 this foundation had established two business administration institutes, one in Baku and one in Celalabat, Kyrgyzstan, and one international relations institute, again in Celalabat. ${ }^{65}$ The head of the foundation, Turan Yazgan, argued that these countries were in dire need of good managers, and thus the priority of their foundation was to establish business administration and international relations institutes. ${ }^{66}$ The language of instruction in these institutes was Turkish and the teaching staff were Turkish nationals. All these institutes accepted both local students and students from Turkey. In September 2003 a total of 871 students attended all three institutes, 45 of whom were Turkish. ${ }^{67}$ This foundation also established Turkish language departments within various universities in Kazakhstan and Dagestan as well as high schools in Azerbaijan, Kazakhstan and Tatarstan and provided technical assistance to them. ${ }^{68}$ Just as in the foundation's other educational institutions, the language of instruction in these high schools was Turkish. Textbooks were provided for the students free of charge, and the education, as the website of the foundation describes, was based on Ismail Gaspirinsky's principle of 'unification in language, thought and action, and expressing this wherever possible'. ${ }^{69}$

\section{Conclusion: any impact at all?}

This article has described Turkey's educational exchange campaign in the Turkic Republics of the former Soviet Union and Eurasia in the past decade. The aim of this campaign was to help create the next generation of elites familiar with Turkish culture and language, as well as with the principles of a market economy. In other words, the goal was a thorough cultural reorientation.

This campaign operated in two different ways. First, there were students, mostly at the university level, who were invited to Turkey on scholarships from the Turkish government; second there were schools, mostly at the secondary school level, that were established in the Turkic Republics of the former Soviet Union and in Eurasia by the Turkish state and private parties. In this case, private schools, as described above, outnumbered the state ones established and operated by the Turkish Ministry of National Education. Both trends, inviting students on scholarships to Turkey and taking Turkish education to these countries, illustrated the idea that educational exchange could become one of the country's most important foreign policy tools. Moreover, the dominance of non-state actors, especially foundations and en- 
trepreneurs connected with the Nurcu and other communities, is a good example of how non-state actors can be extensions of the foreign policy of a country when the aims of the state and the non-state actors overlap to a certain degree.

In the end, however, Turkish educational endeavours, both public and private, were not problem free. Over the years, the overall number of students coming from the Turkic Republics of the former Soviet Union on scholarships declined steadily. The decline was due to financial as well as political reasons. Most of the time the stipends were very small and were paid irregularly. The rift between the Uzbek and the Turkish state caused by Uzbek allegations of fundamentalism became one of the reasons for the withdrawal of Uzbek students from Turkey. Similar reasons were at work in school closures in Uzbekistan as well. Nevertheless, Turkish elites frequently state their keen and continuing interest in this educational exchange and have taken measures to pursue it. In September 2002, for example, the Turkish Ministry of National Education signed a protocol regarding the exchange of students between Turkey and Kazakhstan, ${ }^{70}$ and in November 2002, in addition to the already existing Turkish schools, the teaching of Turkish started at five different elementary schools in Baku. $^{71}$

What has been the overall impact of this exchange? The goal of this article was to assess the intent of this educational exchange; its impact is beyond the scope of the present study, and is a topic for future research. Has the goal of creating a stratum of elites familiar with Turkey, Turkish culture and language as well as market economy principles been achieved? It is doubtful whether a 10-12 year period is long enough to make a very clear and all-encompassing assessment. Furthermore, this kind of evaluation requires a massive amount of institutional and financial support. Consequently, given the difficulties of doing an all-encompassing evaluation, data gathered so far regarding the impact of this educational exchange initiated by the Turkish state and private entrepreneurs have been either anecdotal or, at best, limited in scope. Most of the anecdotal evidence comes from news reports based on the views of various people commenting on the quality of these educational ties as well as the success or failure of these institutions. ${ }^{72}$ There also have been several studies involving the surveying of students studying in Turkish schools in Azerbaijan, Turkmenistan and Kyrgyzstan, with an attempt at measuring the possible impact of the education on their national identification. However, as stated before, these surveys were very limited in scope, examining only a handful of students studying at Turkish schools in only a couple of different countries. No matter how small these studies were, the conclusion they arrived at was that these Turkish schools, public and private, were instrumental in disseminating the idea of common origins with Turkey and the Turkic republics where these studies were conducted. ${ }^{73}$ So far, no studies have been conducted on the students who came to study in Turkey on scholarships provided by the Turkish state. But the declining number of students coming to Turkey every year, as well as the high drop-out rate, may possibly be interpreted as indicating certain limits to this Great Student Exchange as well as to the goal of creating future generations of elites in the newly independent states of Eurasia.

In sum, education can be used as one of the most direct means to mould the political culture of a target country by attempting to create a generation of elites familiar with and sympathetic to the culture and to the country that provides the 
education. However, it may still be too early to make a full-fledged assessment of the effects of these educational ties. What this article illustrated was the intent of the Turkish state to make education one of the tools of its foreign policy. Based on the experience in its own history, Turkey was very well aware of this tool right from the beginning and, as this article demonstrated, used this feature to its fullest ability to create a 'Turkic identity'.

\section{Bilkent University}

\footnotetext{
${ }^{1}$ The literature on the role of education in foreign policy is quite limited. The existing literature usually describes the American educational efforts during the Cold War. See for example Liping Bu, 'Educational Exchange and Cultural Diplomacy in the Cold War', Journal of American Studies, 33, 3, 1999, pp. 393-415; Frank A. Ninkovich, The Diplomacy of Ideas (Cambridge, Cambridge University Press, 1981); Philip H. Coombs, The Fourth Dimension of Foreign Policy: Educational and Cultural Affairs (New York, Harper and Row, 1964).

${ }^{2}$ Alan Makovsky \& Sabri Sayari, 'Introduction', in Alan Makovsky \& Sabri Sayari (eds), Turkey's New World: Changing Dynamics in Turkish Foreign Policy (Washington, DC, The Washington Institute for Near East Policy, 2001), pp. 2-3; Alan Makovsky, 'A New Activism in Turkish Foreign Policy', SAIS Review, 19, 1, Winter/Spring 1999, pp. 92-113; Kenneth McKenzie, 'Turkey's Circumspect Activism', The World Today, 49, February 1993, pp. 25-26; Kemal Kirişçi, 'New Patterns of Turkish Foreign Policy Behavior', in Çiğdem Balim et al. (eds), Turkey: Political, Social and Economic Challenges in the 1990s (Leiden, New York, and Cologne, E. J. Brill, 1995), p. 1.

${ }^{3}$ Turkish Embassy.Org at Washington, DC, http://www.turkey.org/governmentpolitics/regionscentralasia.htm, accessed 12 September 2003.

${ }^{4}$ Ernest Gellner, Nations and Nationalism (Ithaca, NY, Cornell University Press, 1983), p. 36; William A. Reed, 'Curriculum as an Expression of National Identity', Journal of Curriculum Supervision, 15, 2, 2000, pp. 113-133: Carolyn P. Boyd, Historia Patria: Politics, History and National Identity in Spain, 1875-1975 (Princeton, NJ, Princeton University Press, 1997).

${ }^{5}$ Köksal Toptan, Türk Cumhuriyetleri Ĕ̆itim Bakanlari Konferansi Açiliş Konuşmasi (16-23 Mayts 1992), p. 11.

${ }^{6}$ Süleyman Demirel, 'Cumhurbaşkani Sayin Süleyman Demirel'in TBMM'nin 20. Dönem 4. Yasama Yili Açilişinda Yaptiği Konuşma', in Cumhurbaşkant Sayin Süleyman Demirel'in Türkiye Büyük Millet Meclisinde Yaptiği Konuşmalar, p. 154; Süleyman Demirel, 'Cumhurbaşkani Sayin Süleyman Demirel'in TBMM'nin 21. Dönem 2. Yasama Yili Açilişinda Yaptiği Konuşma', in Cumhurbaşkani Sayin Süleyman Demirel'in Türkiye Büyük Millet Meclisinde Yaptiği Konuşmalar, p. 221.

${ }^{7}$ Milli Eğitim Bakanliği, Türk Cumhuriyetleri ve Türk Topluluklarina Yönelik Hizmetler (19921993) (Ankara, Milli Eğitim Bakanliği Basimevi, 1993), p. 22.

${ }^{8}$ Interview with a Ministry of Foreign Affairs official in Ankara, 18 January 2002. See also Toptan, Türk Cumhuriyetleri Eğitim Bakanlari Konferansi Açiliş Konuşmasi (16-23 Mayis 1992), p. 11.

9 'Central Asian Diplomats Train in Turkey', FBIS-SOV-92-119, 19 June 1992.

${ }^{10}$ Avrasya Dosyasi, no. 107, September 1998, p. 8. In 1998 this training programme also started to accept young diplomats from several African countries.

${ }_{11}$ MEB 2001, http://www.meb.gov.tr, accessed 30 December 2001.

${ }^{12}$ Milli Eğitim Bakanliği, Türk Cumhuriyetleri ve Türk Topluluklarina Yönelik Hizmetler (1992-1993), p. 11.

${ }^{13}$ Avni Akyol, Türkiye Büyük Millet Meclisi Tutanaklari, 29 April 1993, Session: 97/1; Ali Dinçer, Türkiye Büyük Millet Meclisi Tutanaklari, 6 December 1994, Session: 46/1, p. 166; Nevzat Ayaz, Türkiye Büyük Millet Meclisi Tutanaklari, 6 December 1994, Session: 46/1, pp. 168-169; 'Turkish Universities Home to Nearly 10,000 Turkic Students', Turkish Daily News, 29 January 1997, http://www.turkishdailynews.com/old_editions/01_29_97/for.htm\#f4, accessed 30 March 2003.

${ }^{14}$ Milli Eğitim Bakanliği, Türk Cumhhuriyetleri ve Türk Topluluklarina Yönelik Hizmetler (1992-1993), p. 19.

${ }^{15}$ Süleyman Demirel, 'Cumhurbaşkani Sayin Süleyman Demirel'in Milliyet Gazetesine Verdiği Mülakat', in Cumhurbaşkani Sayin Süleyman Demirel'in Gazetelere Verdikleri Mülakatlar, p. 1011.
} 
An official from the Turkish Ministry of Foreign Affairs expressed the same view, saying that some degree of failure was quite natural (interview with an official of the Ministry of Turkish Foreign Affairs in Ankara, 18 January 2002).

16 'Uzbek President Recalls 2,000 Students From Turkey', FBIS-SOV-97-237, 25 August 1997; Enis Berberoğlu, Öbür Türkler: “Büyük Oyun” un Milliyetçi Süvarileri (İstanbul: Doğan Kitapçilik, 1999), pp. 120-127.

17 'Uzbek Delegation Arrives for Talks on Education', FBIS-WEU-94-107, 25 September 1994.

${ }^{18}$ Berberoğlu, Öbür Türkler: “Büyük Oyun” un Milliyetçi Süvarileri, pp. 120-127.

${ }^{19}$ MEB İstatistik, http://www.meb.gov.tr/stats/Apk2002/67.htm, accessed 5 February 2003.

20 'Ankara Denies Uzbek Opposition Leader in Turkey', FBIS-WEU-1999-0317, 17 March 1999.

21 'Ecevit: El Koyma Görüşülmedi', Hürriyet, 22 June 1999, http://hurweb01.hurriyet.com.tr/ hur/turk/99/06/22/gundem/08 gun.htm, accessed 15 June 2001.

${ }^{22}$ Sami Kohen, 'Türk Dünyasinda Yeni Atilim', Milliyet, 27 August 1997, http:// www.milliyet.com.tr/1997/08/27, accessed 25 November 2001.

${ }^{23}$ MEB 2001 report, http://www.meb/gov.tr, accessed 30 December 2001.

${ }^{24}$ Türkiye Büyük Millet Meclisi Tutanaklari, 21 February 1995, Session: 77/1, pp. 468-469.

${ }^{25}$ Abbas Güçlü, 'Türki Öğrenciler', Milliyet, 26 May 2000, http://www.milliyet.com/2000/05/26/ yazar/guclu.html, accessed 26 May 2000.

${ }^{26}$ Abdulhaluk Çay, Türkiye Büyük Millet Meclisi Tutanaklari, 15 June 2001, http:// www.tbmm.gov.tr, accessed 26 December 2001.

${ }^{27}$ Interview with a Ministry of Foreign Affairs official in Ankara, 18 January 2002.

${ }^{28}$ Abdulhaluk Çay, Türkiye Büyük Millet Meclisi Tutanaklari, 15 June 2001, http:// www.tbmm.gov.tr, accessed 26 December 2001.

${ }_{29}$ İsmail Cem, Dişişleri Bakani Sayin İsmail Cem'in Dişişleri Bakanliği 2002 Mali Yili Bütçe Tasarisini Türkiye Büyük Millet Meclisi Genel Kurulu’na Takdimi Vesilesiyle Hazirlanan Kitapçik (Ankara, n.p., 2001), p. 28.

30 'Anatolian high school' is a term that is used for schools that have English as the language of education.

${ }^{31}$ Türkiye Büyük Millet Meclisi Tutanaklari, 21 February 1995, Session: 77/1, pp. 468-469. Hoca Ahmet Yesevi University has its executive board in Ankara and campuses in three different cities of Kazakhstan. The teaching languages of the university are Kazakh, Turkish and Russian. Of the 14,044 students, 489 are from Turkey. The university has 1,041 academic staff, 983 of whom are Kazakh and 43 are Turkish; see http://www.yesevi.edu.tr, accessed 22 October 2002.

${ }^{32}$ Hulusi Turgut, 'Fetullah Gülen ve Okullari', Yeni Yüzyil, 30 January 1998, p. 6.

${ }^{33}$ Hulusi Turgut, 'Fetullah Gülen ve Okullari', Yeni Yüzyil, 25 January 1998, p. 6.

${ }^{34}$ Ömer Laçiner, 'Postmodern Bir Din Hareketi: Fetullah Gülen Hoca Cemaati', Birikim, no. 76, August 1995, p. 10; M. Hakan Yavuz, 'Towards an Islamic Liberalism? The Nurcu Movement and Fetullah Gülen', The Middle East Journal, 53, 4, Autumn 1999, p. 596.

${ }^{35}$ Cennet Engin Demir et al., 'The Role of Turkish Schools in the Educational System and Social Transformation of Central Asian Countries: the Case of Turkmenistan and Kyrgyzstan', Central Asian Survey, 19, 1, 2000, pp. 141-155; Hulusi Turgut, 'Fetullah Gülen ve Okullari', Yeni Yüzyil, 23 January 1998, p. 6; Hulusi Turgut, 'Fetullah Gülen ve Okullari', Yeni Yüzyil, 30 January 1998, p. 6; Hulusi Turgut, 'Fetullah Gülen ve Okullari', Yeni Yüzyil, 31 January 1998, p. 6.

36 'Onlar da Desteklemiş', Hürriyet, 22 June 1999, http://hurweb01.hurriyet.com.tr/hur/turk/99/ 06/22/gundem/03gun.htm, accessed 15 June 2001. For Turkish Ministry of Foreign Affairs officials, on the other hand, these reference letters written by high-level officials were quite natural because these schools were no different from any other commercial enterprises that were established in the newly independent states.

${ }^{37}$ Şerif Mardin, Religion and Social Change in Modern Turkey: The Case of Bediüzzaman Said Nursi (Albany, State University of New York Press, 1989), p. 8.

${ }^{38}$ Ibid., p. 77.

${ }^{39}$ Ibid., pp. 77-79, 86; Paul Dumont, 'Disciples of Light: The Nurcu Movement in Turkey', Central Asian Survey, 5, 2, 1986, pp. 45-46.

${ }^{40}$ Hulusi Turgut, 'Fetullah Gülen ve Okullari', Yeni Yüzyil, 15 January 1998, p. 6.

${ }^{41}$ Ibid.

${ }^{42}$ Hulusi Turgut, 'Fetullah Gülen ve Okullari', Yeni Yüzyil, 2 February 1998, p. 6.

${ }^{43}$ Hulusi Turgut, 'Fetullah Gülen ve Okullari', Yeni Yüzyil, 16 January 1998, p. 6.

${ }^{44}$ Ibid.

${ }^{45}$ Hulusi Turgut, 'Fetullah Gülen ve Okullari', Yeni Yüzyil, 22 January 1998, p. 6.

${ }^{46}$ Hulusi Turgut, 'Fetullah Gülen ve Okullari', Yeni Yüzyil, 17 January 1998, p. 8. 
${ }^{47}$ Ibid., Hulusi Turgut, 'Fetullah Gülen ve Okullari', Yeni Yüzyil, 20 January 1998, p. 6.

${ }^{48}$ Hulusi Turgut, 'Fetullah Gülen ve Okullari', Yeni Yüzyil, 24 January 1998; The Economist, 8 July 2000, p. 52. The reason for the support was not only these schools. By declaring 'tesettür' (the covering of Muslim women) a 'detail', and calling for a social consensus, Fetullah Gülen initially managed to present his movement as a possible future alternative to the religious Welfare Party. Because of this, before the December 1995 general election almost all major party leaders visited Fetullah Gülen and tried to gain his and his followers' support against the Welfare Party. Furthermore, the Nurcu community also tried to maintain a good relationship with the state. Gazeteciler and Yazarlar Vakfi (The Journalists' and Writers' Foundation), which was closely associated with the Nurcu community and whose honorary head was Fetullah Gülen, gave former President Demirel, former Minister of Foreign Affairs Hikmet Çetin and the head of the Turkish Grand National Assembly various awards. However, it was only former Army Chief of Staff Ismail Hakki Karadayi who rejected the award from this foundation, indicating the doubts of the Turkish armed forces about Fetullah Gülen and his Nurcu community. See for example 'Islamic Sect Leader Contacts Party Leaders', Turkish Daily News, 26 June 1995, p. 3, and 'Onlar da Desteklemiş', Hürriyet, 22 June 1999, http://hurweb01.hurriyet.com.tr/hur/turk/99/06/22/gundem/03gun.htm, accessed 15 June 2001.

49 'Özbekistan, Fetullahçilarin Peşinde', Cumhuriyet, 16 March 2000, p. 12.

${ }^{50}$ Berberoğlu, Öbür Türkler: "Büyük Oyun "un Milliyetçi Süvarileri, p. 126.

${ }^{51}$ MEB 2001 report, http://www.meb.gov.tr, accessed 30 December 2001; 'Özbekistan, Fetullahçilarin Peşinde', Cumhuriyet, 16 March 2000, p. 12.

${ }_{52}$ Right-wing newspapers, and especially Zaman, were quite instrumental in disseminating Gülen's views; see for example Zaman, 21 June 1999, 22 June 1999, 23 June 1999, 29 June 1999; also Yeni Şafak, 20 June 1999, 23 June 1999, Yeni Asya, 21 June 1999 and Milli Gazete, 23 June 1999; see also Ferhat Bariş, Maskeli Balon: Medyatik Bir Infazin Anatomisi (Istanbul; Timaş Yayinlari, 1999).

53 'DGM 10 Yil Ağir Hapis İstemiyle Dava Açti ve Uyardi', Hürriyet, 31 August 2000, http://www.hurriyet.com.tr/hur/turk/00/09/01/turkiye/02tur.htm, accessed 22 June 2001; Douglas Frantz, 'Turkey Assails a Revered Islamic Moderate', New York Times, 25 August 2000, p. 4; Jeanne Moore, 'Turkey: Islamicist Sought', New York Times, 12 August 2000, p. 4.

${ }^{54}$ In March 2003 newspapers reported that there was the possibility of granting amnesty to Fetullah Gülen; see 'Fetullah Hoca da 'Af' Kapsammda', Milliyet, 11 March 2003, www.milliyet.com.tr/2003/03/11/guncel/gun10.html, accessed 11 March 2003, and 'Gökçer Tahincioğlu 'Gülen'in Avukati 'Beraat' Peşinde', Milliyet, 12 March 2003, www.milliyet.com.tr/2003/03/ 12/guncel/gun20.html, accessed 13 March 2003.

${ }^{55}$ Kemal İlter, 'Ambassadors Back Gülen Schools in Asia', Turkish Daily News, 29 June 2000, http://www.turkishdailynews.com/old-editions/06_29_00/for.htm\#f3, accessed 29 March 2003.

${ }^{56}$ Önder Yilmaz Tiran, 'Ecevit, Gülen'e Siper', Milliyet, 1 March 2000, http://www.milliyet.com/ 2000/03/01/siyaset/siy05.html, accessed 3 March 2000; The Economist, 8 July 2000, p. 52.

${ }^{57}$ Ebru Toktar, 'Şeriatçilara Karşi Eğitim Ataği', Cumhuriyet, 23 October 2000, p. 12.

${ }^{58}$ Ibid.

59 'Kerimov and Cem Work to Thaw Turk-Uzbek Relations', Turkish Daily News, 4 October 2000, www.turkishdailynews.com/old_editions/10_04_00/for.htm\#f4, accessed 24 March 2003. Turkey has since tried to improve its rēations with Uz̄ military aid to Uzbekistan and $\$ 610,000$ in 2002. Turkey also trained Uzbek soldiers ('Turkey Equips, Trains Uzbek Military', Turkish Daily News, 7 March 2002, http:// www.turkishdailynews.com/old_editions/03_07_02/for.htm\#f5, accessed 31 March 2003.

60 'Turkey Denies Targeting Gülen Schoōs in Central Asia', Turkish Daily News, 24 October 2000,www.turkishdailynews.com/old_editions/10_24_00/for.htm\#f9, accessed 30 March 2003.

61 'Fetullah Gülen' in Okullarina Gözalti', Hürriyet, 6 February 2001, http:// www.hurriyet.com.tr/hur/turk/01/02/06/turkiye/63tur.htm, accessed 2 February 2003.

62 'Fetullah' in Ders Kitaplari İncelemede', Milliyet, 16 February 2001, http://www.milliyet.com/ 2001/02/16/guncel/gun10.html, accessed 16 February 2001. A close eye was also kept on educational institutions associated with the Nurcu community in Turkey.

${ }^{63}$ In May 2002, in the Karachai-Cherkessia region of the Russian Federation, a high school that was known to have ties to the Nurcu communities was closed down by the authorities in order to 'protect the young against hostile ideology'; see 'Russia: Islamic Extremists Schools Closed in Karachai Cherkessia', FBIS-SOV-2002-0528, 28 May 2002. This was followed by other school closures elsewhere in Russia; see Cenk Başlamiş, 'Rusya'daki Türk Okullari Kapatiliyor', Milliyet, 28 August 2003, http://www.milliyet.com.tr/2003/08/28/siyaset/siy07.html, accessed 10 September 2003. The reason that was given by the authorities was the same; see Cenk Başlamiş, 'Rusya'daki 
Gülen Okullari Tehlikede', Milliyet, 1 May 2003, http://www.milliyet.com.tr/2003/05/01/siyaset/ siy04.html, accessed 1 May 2003; Cenk Baslamiş, 'Türk Okullarinin Beynine Yasak', Milliyet, 7 September 2003, http://www.milliyet.com.tr/2003/09/07/siyaset/siy01.html, accessed 15 September 2003.

64 'Mallari Tehlikede', Hürriyet, 22 June 1999, http://hurweb01.hurriyet.com.tr/hur/turk/99/06/ 22/gundem/02gun.htm, accessed 15 June 2001.

${ }^{65}$ TÜDAV webpage, http://www.tdav.org/etkinlik/yd_egitim.htm, accessed 24 April 2001.

66 'Turanci Diyen Ahmaktir', Nokta, 7 June 1992, pp. 26-27.

${ }^{67}$ TÜDAV website, http://www.tdav.org/etkinlik/yd egitim.htm, accessed 24 April 2001.

68 Ibid.

69 Ibid.

${ }^{70}$ BBC Monitoring Central Asia Unit, 25 September 2002.

71 'Turkish Education Starts in Baku', Turkish Daily News, 15 November 2002, www.turkisdailynews.com/old_editions/11_15_02/dom.htm\#d6, accessed 6 March 2003.

${ }^{72}$ See for example 'Islamic Evangelists: Gülen Eyes the Generals', The Economist, 8 July 2000, p. 52; Abdullah Akkuş, 'Tutuklu Türkleri Alin Götürün', Milliyet, 10 January 2003, http:// www.milliyet.com.tr/2003/01/10/siyaset/siy04.html, accessed 10 January 2003; İsmail Altunsoy \& Ahmet Dönmez, 'Turk Okullarini Öven Nazarbayev İşadamlarini Yatirima Çağirdi', Zaman, 22 May 2003, http://www.zaman.com.tr/2003/05/22/dis/h2.htm, accessed 17 September 2003; 'Atatürk'ün Dostu Dostum, Düşmani Düşmanim', Hürriyet, 18 October 2000, p. 24.

${ }^{73}$ Engin Demir et al., 'The Role of Turkish Schools in the Educational System and Social Transformation of Central Asian Countries', pp. 141-155; Yasemin Kilit Aklar, 'Education and Turkic Identity in Azerbaijan', paper presented at the Fifth Annual Convention of the Association for the Study of Nationalities, 15 April 2000, New York. 
